\title{
Wieś idealna - układ przestrzenny i zabudowa miejscowości Paproć Duża
}

\author{
Małgorzata Dolistowska \\ https://orcid.org/0000-0002-6704-8303 \\ m.dolistowska@pb.edu.pl \\ Wydziat Architektury, Politechnika Białostocka
}

\begin{abstract}
Streszczenie: Artykuł prezentuje okoliczności powstania i historię wsi Paproć Duża założonej w końcu XVIII w. pod nazwą Königshuld w ramach akcji osadniczej obejmującej nieskolonizowane obszary Prus Nowowschodnich. Spośród innych, lokowanych wówczas miejscowości, wyróżnia ją oryginalny układ przestrzenny, oparty o schemat koncentryczno-promienisty. W artykule omówiono okoliczności powstania wsi oraz jej interesującą historię z epizodem związanym z krótkim pobytem Józefa Piłsudskiego. Dokonana została analiza centralnego założenia przestrzennego w kontekście nielicznych, analogicznie rozplanowanych wsi osadniczych założonych na ziemiach polskich w 2. połowie XVIII wieku w ramach kolonizacji fryderycjańskiej.
\end{abstract}

Słowa kluczowe: Königshuld, Paproć Duża, kolonizacja fryderycjańska, założenia koncentryczno-radialne, Prusy Nowowschodnie

\section{Wstęp}

Wieś Paproć Duża położona powiecie zambrowskim (gmina Szumowo, województwo podlaskie) geograficznie przynależy do północno-wschodniej części Niziny Mazowieckiej. Proces kolonizacji tego terenu, podobnie jak całego wschodniego Mazowsza, rozpoczął się w końcu XIV w. i rozwijał dynamicznie w następnych stuleciach; jego efektem jest duże zróżnicowanie form osadniczych. Znajdowały się tu wsie chłopskie w dobrach królewskich i w dobrach szlacheckich, wsie drobnoszlacheckie, wsie biskupie, osady puszczańskie zakładane przez zbiegłych chłopów i spauperyzowaną szlachtę, wreszcie wsie poregulacyjne i pouwłaszczeniowe. Wśród nich Paproć Duża zajmuje miejsce szczególne, wyróżniając się zarówno genezą powstania, nietypową historią, jak i wyjątkowym sposobem rozplanowania. Celem artykułu jest odtworzenie dziejów oraz analiza rozwoju przestrzennego miejscowości, rozpatrywana w kontekście analogicznych realizacji powstałych w trakcie kolonizacji fryderycjańskiej w 2 połowie XVIII w.

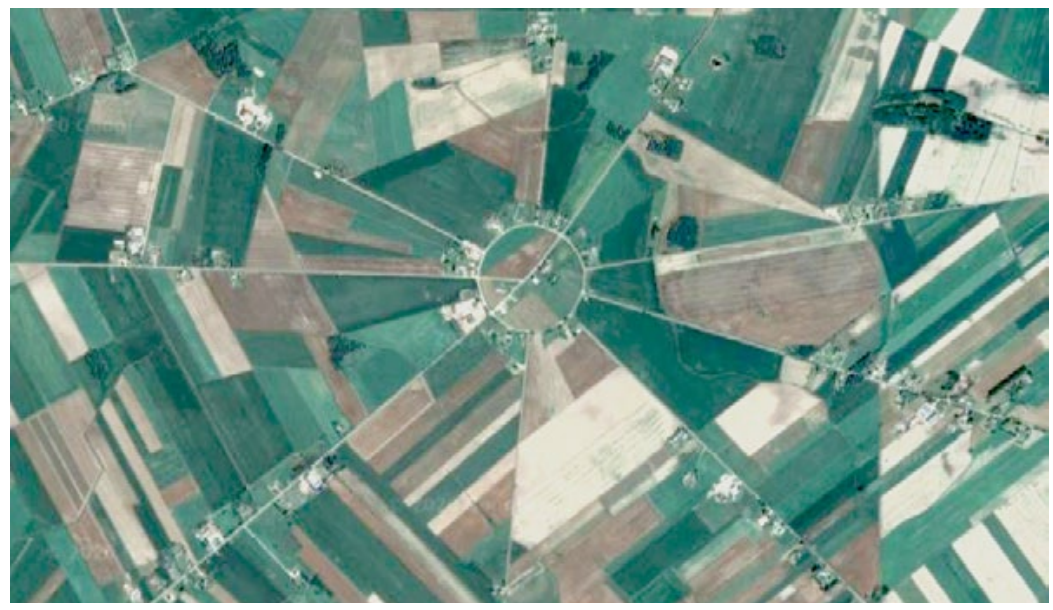

Ryc. 1. Wieś Paproć Duża, widok satelitarny

Źródło: https://www.google.pl/maps/ place/18-305+Paproć+Duża 


\section{Historia miejscowości}

Obszar, na którym leży Paproć Duża i okoliczne wsie (Pęchratka, Srebrna, Kowalewka, Króle) aż do końca XVIII wieku był porośnięty puszczą i niezasiedlony. We wczesnym średniowieczu (XI-XIII w.) był to teren pogranicza polsko-rusko-jaćwieskiego, podlegający do XIII w. rozległej kasztelanii w Święcku nad Bugiem, której znaczna część stanowiła uposażenie biskupstwa płockiego ${ }^{1}$. W posiadaniu biskupim obszar ten pozostał do rozbiorów Polski. Okolice dzisiejszej Paproci to Puszcza Łętowo rozciągająca się od ujścia Nurca do Bugu po okolice Zambrowa oddzielając ziemię łomżyńską od nurskiej. Do 1569 roku biegła tędy granica państwowa z Litwą, a następnie granica między województwami mazowieckim i podlaskim.

Po III rozbiorze Rzeczypospolitej tereny te znalazły się w zaborze pruskim. Rozległe dobra biskupów płockich wraz z nieskolonizowanymi jeszcze resztkami dawnej Puszczy Łętowo - tzw. Puszcza Ruskołęcka, zostały przez władze pruskie skonfiskowane i włączone w granice Prus Nowowschodnich (Neu Ostpreussen), nowoutworzonej jednostki administracyjnej państwa pruskiego. Po dwuletnim okresie tymczasowego zarządzania ustalono trwałą strukturę prowincji, którą podzielono na dwa departamenty z siedzibami w Białymstoku i Płocku. Zarząd każdej z nich sprawowały urzędy Kamer Wojny i Domen podlegające bezpośrednio Generalnemu Dyrektorium w Berlinie. Puszcza Ruskołęcka znalazła się w powiecie ostrowskim departamentu płockiego².

$\mathrm{Na}$ ziemiach wcielonych do Nowych Prus Wschodnich rozpoczęto intensywną akcję kolonizacyjną; inicjatorem akcji był Friedrich Leopold von Schrötter, minister zarządzający prowincją. W departamentach białostockim i płockim wytypowano tereny przeznaczone do zasiedlenia: łącznie około 1576 łanów ziemi, w większości niewykarczowanej. Specjalne przywileje i udogodnienia miały zachęcić kolonistów niemieckich do zamieszkania w wyznaczonych regionach. Osadnikom przysługiwało prawo do darmowego przydziału ziemi bez opłat, kontyngent drewna na wzniesienie budynków mieszkalnych i gospodarczych (lub jego równowartość pieniężna) oraz trzyletnie zwolnienie z wszelkich podatków i zobowiązań na rzecz państwa. Ponadto osoby o szczególnie poszukiwanych zawodach otrzymywały jednorazowe wsparcie finansowe na urządzenie warsztatu. Wszyscy koloniści uzyskiwali pieniądze na podróż i mieli prawo przywozu bez cła całego swego ruchomego majątku. Osadnicy, ich synowie, parobcy, czeladnicy i uczniowie byli też zwolnieni ze służby wojskowej. Jednocześnie opracowano szczegółowy regulamin i plan inwestycji dla kolonii. Wszystkie informacje zawarte były w Rejestrze tych rejonów ziemskich w Prowincji Nowych Prus Wschodnich, które dla wiejskich gospodarstw rolnych kolonistów kwalifikuja się oraz ich powierzchnia ${ }^{3}$. Pierwsi przybysze zaczęli napływać w 1797 roku, jednak właściwa akcja kolonizacyjna rozpoczęła się w latach 1799-1800, kiedy rozpoczęto na szerszą skalę werbunek kolonistów z Rzeszy Niemieckiej.

W departamencie płockim akcję kolonizacyjną nadzorowaną przez prezydenta departamentu Broscoviusa i radcę wojennego i domen Mylkego, prowadzono energicznie i metodycznie, z kilkuletnim wyprzedzeniem sporządzając plany nowych siedlisk. Niebawem powstał szereg nowych osad, a wśród nich kolonia Schröttersdorf (1797 r., w której skład wchodziły wsie w okolicach Płocka: Maszewo, Powsino, Chełpowo, Biała), Güntersruhm (Dzierżążna), Agnesenau (Biele-Brzeżnica), Mylkenau (Wiążewo), Wilkenau (Drwale), Louisenfelde (Nowy Modlin), Broskowendorf (Orzechowo) ${ }^{4}$. Ważnym elementem projektu było zagospodarowanie pustkowi leśnych wokół Ruskołęki, na wschód od Ostrowi, w gminie Jasienica. Rozległe niezamieszkałe obszary pokrywała dzika puszcza "służąca za miejsce pobytu głównie wilkom i niedźwiedziom”. granica rozdzielająca departamenty płocki i białostocki, jednak wkrótce przygraniczna część departamentu białostockiego została przyłączona do okręgu płockiego; celem było utworzenie w tym miejscu jednorodnego zespołu osiedleńczego. Pierwotna koncepcja przewidywała utworzenie rozległej gminy o powierzchni około

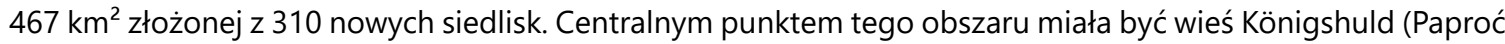
Duża) połączona promieniście z czterema osadami: Königshuld (Paproć Mała), Louisenau (Pęchratka Łowizna), Wilhelmsdorf (Króle) i Mecklemburg (Kowalewko). Zadanie sporządzenia pomiarów i podziału gruntów oraz

1 J. Wiśniewski, Rys dziejów osadnictwa na wschodnim Mazowszu. "Literatura Ludowa” R. VI:1962, z. 4-6, s. 11; A. Kamiński, Pogranicze polsko-rusko-jaćwieskie między Biebrzą i Narwią, "Rocznik Białostocki”, T. IV, Białystok 1963, passim.

2 J. Wiśniewski, op. cit., s. 19.

3 A. Müller, Die preussische Kolonisation in Nordpolen und Litauen 1795-1807, Berlin 1928, s. 51, 88.

4 Ibidem, s. 120; J. Wąsicki, Ziemie polskie pod zaborem pruskim: Prusy Nowowschodnie (Neuostpreussen) 1795-1806, Poznańskie Towarzystwo Przyjaciół Nauk, Prace Komisji Historycznej, Vol. XX, Part 1, Poznań 1963, s. 146.

5 A. Pytlak, Die deutsche Kolonisationbestrebungen auf den Staatsdomänen im Königsreiche Polen von 1793-1864, Lepzig 1917, s. 15. 
projektu kolonii powierzono radcy Kamery Wojny i Domen - von Wedell'owi; wszystkie prace zostały zakończone jesienią 1799 r. Według historyków minister Friedrich Leopold von Schrötter był szczególnie dumny z planów zasiedlenia puszczy Ruskołęckiej i co najmniej dwukrotnie przedstawiał projekty kolonii królowi Fryderykowi Wilhelmowi ${ }^{6}$. Szeroko zakrojony plan kolonizacji został wdrożony tylko w pierwszym etapie, jego dalszą realizację przerwały wydarzenia polityczne i utrata prowincji Nowych Prus Wschodnich na rzecz Rosji po 1807 r. Zasiedlenie puszczy Ruskołęckiej pozostało przedsięwzięciem jedynym w swoim rodzaju - Prusacy próbowali jeszcze karczować i meliorować Puszczę Przasnyską, Omulew i Orzyc, lecz już bez powodzenia.

Pierwsi koloniści przybyli do Königshuld w roku 1803, zaś cała akcja osiedleńcza trwała do roku 1806. Przygotowano i rozmierzono ziemię dla 78 siedlisk, wśród których wydzielono gospodarstwa dla pastora, nauczyciela, młynarza i kowala. W 1806 roku w Paproci osiedlonych było 68 rodzin (nie było jeszcze pastora ani nauczyciela), łącznie - ze służbą i parobkami wieś liczyła 321 osób. Osadnicy przybyli z różnych terenów: większość pochodziła z prowincji pruskiej, 24 rodziny przyjechały z Meklemburgii, osiem rodzin - z Wirtembergii ${ }^{7}$. Wieś nosiła wówczas nazwę Gross Königshuld i administracyjnie należała do departamentu płockiego, powiatu (amt) Jasienica. Po 1807 r. Nowe Prusy Wschodnie przestały istnieć jako jednostka administracyjna podległa państwu pruskiemu; na mocy traktatu w Tylży terytorium zostało podzielone między Cesarstwo Rosyjskie a Księstwo Warszawskie (po 1815 r. - Królestwo Polskie). Miejscowość Gross Königshuld, pod nową nazwą Gross Paproć lub Paproć Duża (wymiennie stosowano również nazwę Paproć Wielka) ${ }^{8}$ znalazła się wówczas w obwodzie ostrołęckim województwa płockiego, gminie i parafii Jasienica, zaś po reformie administracyjnej przeprowadzonej w zaborze rosyjskim w 1866 r. - w guberni łomżyńskiej.

Wieś Paproć Duża wraz z czterema sąsiadującymi miejscowościami tworzyła zamkniętą enklawę osadnictwa pruskiego w zaborze rosyjskim; społeczność ta krótko po osiedleniu się w nowym miejscu, w wyniku wydarzeń historycznych została nagle pozbawiona dotychczasowej protekcjonistycznej opieki władzy administracyjnej. Przez pierwsze dekady mieszkańcy pozbawieni byli szkoły i własnej świątyni. W czasach pruskich czyniono przygotowania do erygowania w Paproci gminy ewangelickiej, jednak planu nie udało się wówczas zrealizować. Dzieci pobierały nauki szkolne nieregularnie, sporadyczna była również opieka duszpasterska - raz na kilka miesięcy dojeżdżał tu pastor z Suwałk lub z Węgrowa ${ }^{9}$. Dopiero w 1837 r. Generalny Konsystorz Wyznań Ewangelickich podjął decyzję o urządzeniu parafii, motywując ją doniesieniami raportu superintendentury płockiej, że „w okolicach dóbr rządowych Paproci Wielkiej znajduje się bardzo znaczna liczba wyznawców ewangelickich pozbawiona od czasu swego wprowadzenia się do kraju wszelkiej pomocy religijnej i dla tej przyczyny pozostająca w najwyższym stopniu demoralizacji"10. W tym samym roku wyasygnowano fundusze na budowę kościoła i plebanii oraz oddelegowano pastora Teodora Küntzela, który pozostał w Paproci do 1838 r. nadzorując rozpoczęte prace budowlane. W czasie działalności jego następcy - księdza Johanna Gotlieba Schliecke, wzniesiono dom pastora i przynależące doń zabudowania gospodarcze oraz zakończono budowę kościoła ${ }^{11}$. Plebanię przekazano do zamieszkania w 1843 r. zaś w dniu 7 grudnia 1848 r. spisano protokół odbioru budynku kościoła wraz z rachunkiem za całość prac ${ }^{12}$.

Parafia ewangelicka w Paproci Dużej była gminą rozległą, obejmowała bowiem otaczające ją wsie zasiedlone niemieckimi osadnikami. Według wykazu z dnia 8 sierpnia 1839 liczyła łącznie 371 rodzin (1695 dusz) $)^{13}$. Po śmierci pastora Schlieckego w 1848 r. posługę duszpasterską w Paproci pełnili kolejno: wikariusz Karol Wagner i Juliusz Mrongowiusz ${ }^{14}$. Za czasów tego ostatniego przeprowadzono w 1853 r. remont kościoła, a w kolejnych latach zbudowano nowy dom pastora massiv wymurowany w miejscu starego drewnianego budynku,

6 A. Müller, op. cit., s. 123, 137. Nie udało się odnaleźć bliższych informacji o radcy von Wedell, jednak zważywszy na tytulaturę musiał być wysokim urzędnikiem Kamery, być może dyrektorem wydziału budowlanego - taka sytuacja miała miejsce np. w departamencie białostockim, gdzie dyrektor budowlany Mateusz Braun pełnił analogiczną funkcję; zob.: M. Dolistowska, W poszukiwaniu tożsamości miasta. Architektura i urbanistyka Białegostoku w latach 1795-1939, Białystok 2009, s. 61.

7 Müller, op. cit., aneks, str. nlb. Dane dotyczą łącznie Paproci Dużej i Paproci Małej.

8 Stownik geograficzny Królestwa Polskiego i innych krajów słowiańskich, t. VII, Warszawa 1888, s. 851.

9 E. Kneiefel, Geschichte der Evangelisch-Augsburgische Kirche in Polen, Nürnberg 1961, s. 110.

10 Archiwum Główne Akt Dawnych w Warszawie (dalej AGAD Warszawa), KRSW, Akta Centralnych Władz Wyznaniowych (dalej CWW), sygn 1209: Akta gminy ewangelickiej w Paproci województwie płockim 1825-1843, s. 67.

11 E. Kneifel, Die Pastoren der evang.-augsb. Kirche in Polen, Nürnberg 1961, s. 119.

12 AGAD Warszawa, CWW, sygn. 1210, k. 201.

13 Ibidem, s. 272: Wykaz Miast Wsi i Osad należeć mających do parafii ewangelickiej Paproć Wielka oraz ich ludność.

14 E. Kneifel, die Pastoren..., s. 120. 
będącego już bardzo złym stanie technicznym. W 1883 miejscowym pastorem został na trzy kolejne lata Karol Doll. Paproć Duża liczyła wówczas 415 mieszkańców i 47 gospodarstw; obok kościoła i plebanii znajdowała się tu również szkoła elementarna oraz cmentarz ${ }^{15}$. W latach 1886-1926 parafią zarządzał Kacper Mikulski, pastor parafii łomżyńskiej, który pod swoją pieczą miał również parafię w Węgrowie, co było spowodowane znacznym rozproszeniem ludności wyznania ewangelickiego w guberni łomżyńskiej ${ }^{16}$. W dniu 19 lipca 1899 r. pastor Mikulski udzielił ślubu późniejszemu marszałkowi Polski - Józefowi Piłsudskiemu i Marii Kazimierze Juszkiewicz z domu Poklewskiej. Uroczystość odbyła się w kościele w Paproci Dużej, zapis w księdze stanu cywilnego tamtejszej gminy ewangelickiej określał Piłsudskiego jako kawalera, zaś jego narzeczoną - „rozwiedzioną z winy męża"17. Świadkami ślubu byli bracia pana młodego Adam i Jan Piłsudscy. Kilka dni wcześniej, 12 maja 1899 r., Józef Piłsudski dokonał konwersji na wyznanie ewangelicko-augsburskie, akt ten spowodowany był prawdopodobnie niemożnością poślubienia w kościele rzymsko-katolickim rozwiedzionej Marii Juszkiewiczowej ${ }^{18}$. Osoba pastora Kacpra Mikulskiego nie była w tych wydarzeniach przypadkowa - duchowny, były powstaniec styczniowy, aktywnie uczestniczył w ruchu niepodległościowym i blisko współpracował z Polską Partią Socjalistyczną. Na plebanii w Łomży znajdował się skład bibuły, czasowo działała konspiracyjna drukarnia, niejednokrotnie otrzymywał tutaj schronienie ukrywający się przed carskimi żandarmami Józef Piłsudski ${ }^{19}$. Po wybuchu I wojny światowej okupacyjne władze niemieckie z uwagi na patriotyczne zaangażowanie pastora Mikulskiego odsunęły go od funkcji duszpasterskich; ponownie objął swą parafię po $1918 \mathrm{r}$. i administrował nią do roku $1926^{20}$.

W czasie I wojny światowej mieszkańcy Paproci Dużej zostali ewakuowani w głąb Rosji. Podczas działań wojennych spłonęła doszczętnie zabudowa wsi, oprócz kościoła i plebanii zachowały się tylko trzy domy mieszkalne. W dwudziestoleciu międzywojennym zmniejszyła się nieco liczebność parafii, liczyła ona w tym czasie 1115 osób (w 1913 r. było to 1450 dusz). Od 1919 r. w Paproci działał chór mieszany i orkiestra dęta. W dwóch szkołach powszechnych z językiem wykładowym niemieckim (w Paproci i w Srebrnym Borku) uczyło się 135 dzieci ${ }^{21}$. W dniach 25 i 26 czerwca 1938 r. gmina ewangelicka w Paproci Dużej uroczyście świętowała swój 100-letni jubileusz. Od września 1939 r. do czerwca 1941 Paproć Duża znajdowała się pod okupacją sowiecką. Mieszkańcy pochodzenia niemieckiego zostali przesiedleni w okolice Mławy i Nidzicy; po roku większość z nich wyjechała do Meklemburgii i Szlezwiku-Holsztyna. Wieś została zasiedlona przez nową ludność z terenów przygranicznych. Ten stan rzeczy utrzymał się w czasie okupacji niemieckiej, kiedy tereny te zostały wcielone do Rzeszy. Po 1945 r. nastąpił proces legalizacji użytkowania ziemi i zabudowań przez nowych osadników; swoją własność zachowali natomiast przedwojenni mieszkańcy narodowości polskiej.

\section{Projekt i jego realizacja. Charakterystyka zabudowy}

Plan założenia przestrzennego centrum wsi Königshuld (Paproć Duża) powstał - jak czytamy w przytoczonym wyżej raporcie - w 1799 r. Zachowany w zbiorach archiwalnych niedatowany projekt zatytułowany Grundriss von der im Mittelpunkt des Colonie Dorffs A anzulegenden Kirche des Kirchhofes und der umliegenden Etablissements dotyczy lokalizacji kościoła i rozplanowania centrum miejscowości; rysunek był najprawdopodobniej częścią większego zbioru obejmującego pozostałe elementy zespołu osadniczego ${ }^{22}$. Widoczna na nim miejscowość nie ma jeszcze określonej nazwy własnej, anonimowe są również nowo projektowane osady z którymi jest skomunikowana. Identyfikacja miejsca jako późniejszej wsi Königshuld (Paproć Duża) jest możliwa dzięki

\footnotetext{
15 Słownik geograficzny Królestwa Polskiego i innych krajów słowiańskich, t. VII, Warszawa 1888 , s. 851.

16 E. Kneifel, die Pastoren..., s. 33.

17 Ibidem; T. Stegner, Przyjaciel Marszałka pastor Kacper Mikulski (1840-1935), "Gdański Rocznik Ewangelicki”, vol. 3 (2009), s. 87.

18 Fotokopia aktu konwersji Józefa Piłsudskiego na luteranizm wraz z tłumaczeniem na język polski zamieszczona w: „Poseł Ewangelicki” nr 9 , 1964, s. 2; zob. także: ks. J.Warszawski. Studia nad wyznaniowością religüną marszałka Józefa Piłsudskiego, Londyn 1978 r., s. 49.

19 T. Stegner, op. cit. s. $87-95$

20 Ibidem, s. 94. W latach II Rzeczypospolitej pastor Kacper Mikulski jako jedyny duchowny ewangelicki w Polsce otrzymywał pensję państwową W czasie swego złotego jubileuszu w 1931 r. został odznaczony Złotym Krzyżem Zasługi. Zob: E. Kneifel, Die evangelisch-augsburgischen Gemeinden in Polen 1555-1939, Vierkirchen über München 1971, s. 29.

21 Rocznik Ewangelicki, Warszawa 1925, s. 153.

22 AGAD Warszawa, Zbiór Kartograficzny, sygn. 360-62.
} 
oznaczeniu dróg prowadzących do okolicznych istniejących już polskich wsi: Łętownicy, Pęchratki, Andrzejewa, Ruskołęki i Srebrnej.

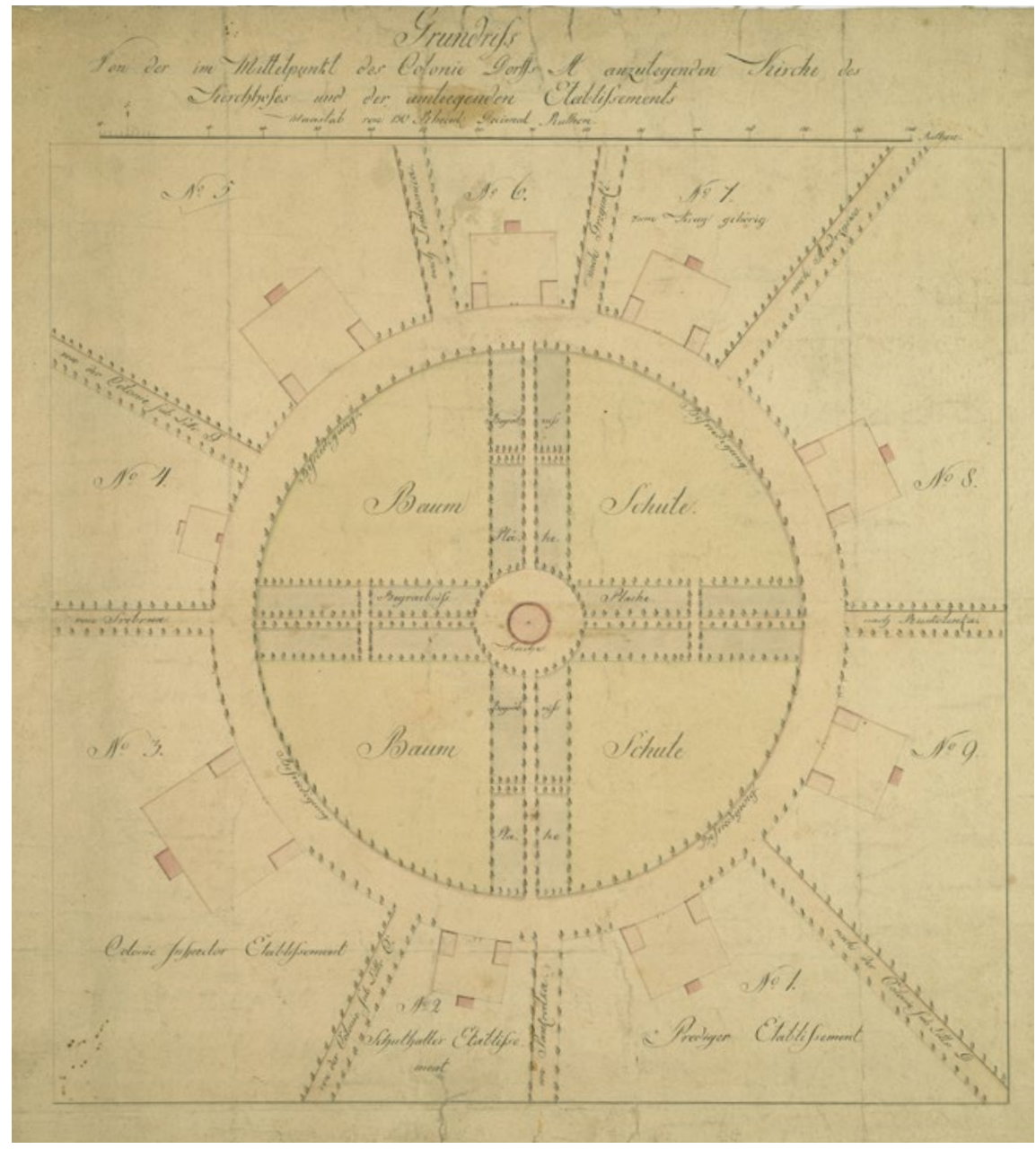

Ryc. 2. Projekt lokalizacji kościoła i rozplanowania centrum miejscowości "A" (późn. Königsghuld-Paproć Duża)

Źródło: AGAD Warszawa, Zbiór Kartograficzny, sygn. 360-62

Nowo projektowana miejscowość miała zaplanowany regularny, symetryczny układ. Centrum stanowił przestronny plac na planie koła o średnicy ponad 300 m., przecięty na cztery części przez cmentarz na rzucie krzyża greckiego. Jego osnową były dwie aleje przecinające się pod kątem prostym, wzdłuż których zaprojektowano obsadzone szpalerami kwatery nekropolii oznaczone jako Begräbniss Platze. Na przecięciu dróg, w środkowym punkcie kolistego placu, zlokalizowano kościół pełniący rolę zwornika całej kompozycji przestrzennej. Ćwierćkoliste przestrzenie wyznaczone przez krzyżowy układ cmentarza oznaczono na planie jako miejsca "szkółki drzewnej" (Baumschule). Rozległe centrum otoczono pierścieniem okrężnej drogi, od której odchodziło promieniście dziewięć traktów w kierunkach oznaczonych na planie: nach Ruskolenka (do Ruskołęki - tłum. M.D.), nach der Collonie sub Litt. D (do kolonii pod lit. D - późniejszej wsi Pęchratka Mała), von Pankratka (z Pęchratki Polskiej), von der Collonie sub Litt. C. (z kolonii pod lit. C - późniejszej Paproci Małej), von Srebrna (ze Srebrnej), von den Collonie sub Litt. G (z kolonii pod lit. G, późniejszego Srebrnego Borku), nach Lentownica (do Łętownicy), nach Grzymki (do Grzymek), nach Andrzejewo (do Andrzejewa). Pomiędzy drogami wytyczono dziewięć siedlisk z zabudowaniami; pierwsze trzy są oznaczone jako należące do pastora, kierownika szkoły i inspektora kolonii, na wprost nich, po przeciwnej stronie okręgu, na posesji nr 7, zlokalizowano karczmę (zajazd). Miejscowość planowana była jako główny ośrodek rozległego zespołu osadniczego, w skład którego wchodziło kilka kolonii zakładanych na surowym korzeniu oraz istniejące już wsie (Pęchratka, Ruskołęka, Łętownica, Grzymki, Srebrna) - miał to być zatem punkt porządkujący i organizujący ład przestrzenny okolicy. Idealizm planu wyraził 
się w doskonale symetrycznym rozplanowaniu miejscowości i lokalizacji kościoła jako dominanty usytuowanej dokładnie w centrum kompozycji przestrzennej, u zbiegu osi wszystkich dziewięciu dróg promieniście odchodzących od kolistej obwodnicy placu.
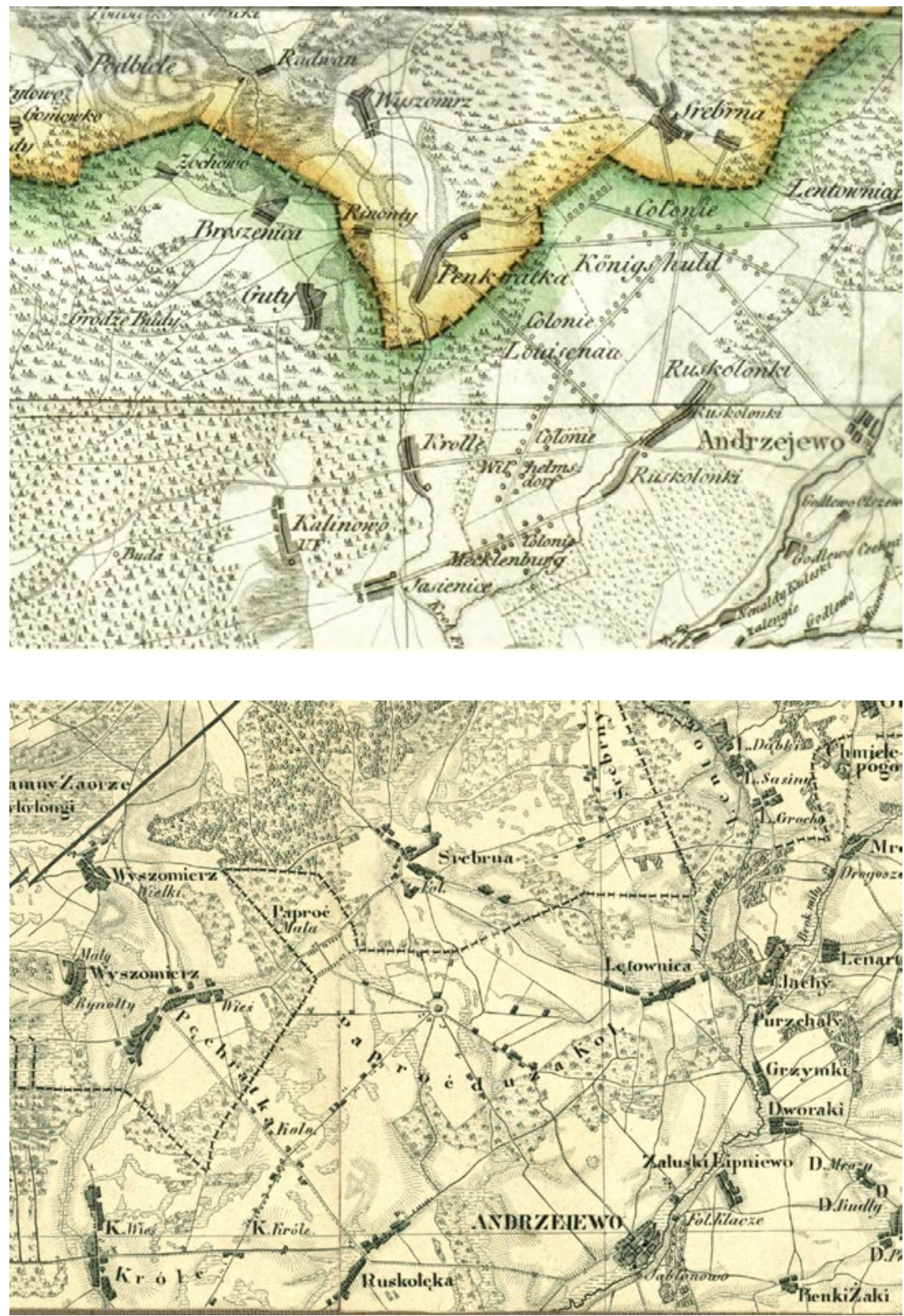

Ryc. 3. Kolonia Königshuld wraz z otaczającymi ją miejscowościami, fragment mapy J. Ch. Textora, Topographish-Militarische Karte vom vormaligem Neu Ostpreussen oder dem jetziger Nördlichen Theil des Herzogthums Warschau nebst dem Russischen District [...], $1806 \mathrm{r}$.

Źródło: https://rcin.org.pl/ dlibra/publication/33118/ edition/31789
Ryc. 4. Fragment Mapy Kwatermistrzostwa, $1839 \mathrm{r}$. Źródło: https://polona.pl/ item/topograficeskaa-karta-carstva-pol-skago-topograficzna-karta-krolestwa-polskiego-carte,Mzc0MjE5 $\mathrm{OA} / 13 / \#$ info:metadata

Realizacja projektu przebiegała początkowo zgodnie z pierwotnym założeniem i zachowaniem zawartych w nim dyspozycji. W pierwszej kolejności wytyczono główne elementy planu: układ centralnej części wsi, sieć drożną oraz siedliska kolonistów usytuowane w układzie radialnym wokół okolnicy i wzdłuż dróg promieniście od niej odchodzących. Układ ten widoczny jest na mapie Nowych Prus Wschodnich z 1806 roku²3 (Ryc. 3). Na 
mapie tej, pośrodku kolistego centrum umieszczony został znak krzyża oznaczający planowany kościół - jego budowę rozpoczęto jednak dopiero trzydzieści lat później.

Kolejna mapa, tzw. Mapa Kwatermistrzostwa z 1839 r. ukazuje istniejący stan rzeczy bardziej precyzyjnie: widoczny jest na niej kolisty plac w centrum wsi porośnięty niską zielenią (być może cmentarz grzebalny, już wówczas istniejący) oraz zaznaczone pośrodku tego obszaru nieregularne zabudowania - prawdopodobnie był to rozpoczynający się budować kościół, plebania i budynki gospodarcze ${ }^{24}$ (Ryc. 4). Przestrzeń centralnego placu została zakomponowana w sposób nieco odbiegający od planowanej, bez regularnego podziału w postaci krzyżujących się alei. Cmentarz prawdopodobnie miał formę nieuporządkowaną, gdyż pierwsza wzmianka o istnieniu nekropolii ewangelickiej w Paproci Dużej pochodzi z roku 1825 i dotyczy prośby mieszkańców tej miejscowości oraz okolicznych kolonii o przydział drewna na ogrodzenie ${ }^{25}$.

Mapa z 1915 r. ukazuje przebiegające przez plac dwie drogi: z Pęchratki Łowizny do Srebrnej oraz z Paproci Małej do Grzymek i Andrzejewa. Zaznaczono również usytuowany centralnie kościół i niewielki cmentarz znajdujący się po wschodniej stronie świątyni, za prezbiterium, przy drodze do Andrzejewa. Na mapie widoczny jest również drugi, mniejszy cmentarz, usytuowany przy drodze do Srebrnego Borku. Nie znamy daty jego założenia, musiało to jednak nastąpić po roku 1886, gdyż zamieszczona w wydanym wówczas tomie siódmym Stownika Geograficznego Królestwa Polskiego krótka informacja o Paproci Dużej wzmiankuje tylko jeden cmentarz należący do tutejszej parafii ewangelickiej ${ }^{26}$. Układ przestrzenny wsi zaznaczony na mapie z 1915 r. zachował się do wybuchu II wojny światowej i widoczny jest również w materiałach kartograficznych z dwudziestolecia międzywojennego. Mapa wojskowa z 1934 r. ukazuje analogiczny schemat miejscowości, dodatkowo widoczne jest usytuowanie zabudowań domu parafialnego naprzeciwko kościoła, po drugiej stronie drogi ${ }^{27}$ (Ryc. 5).

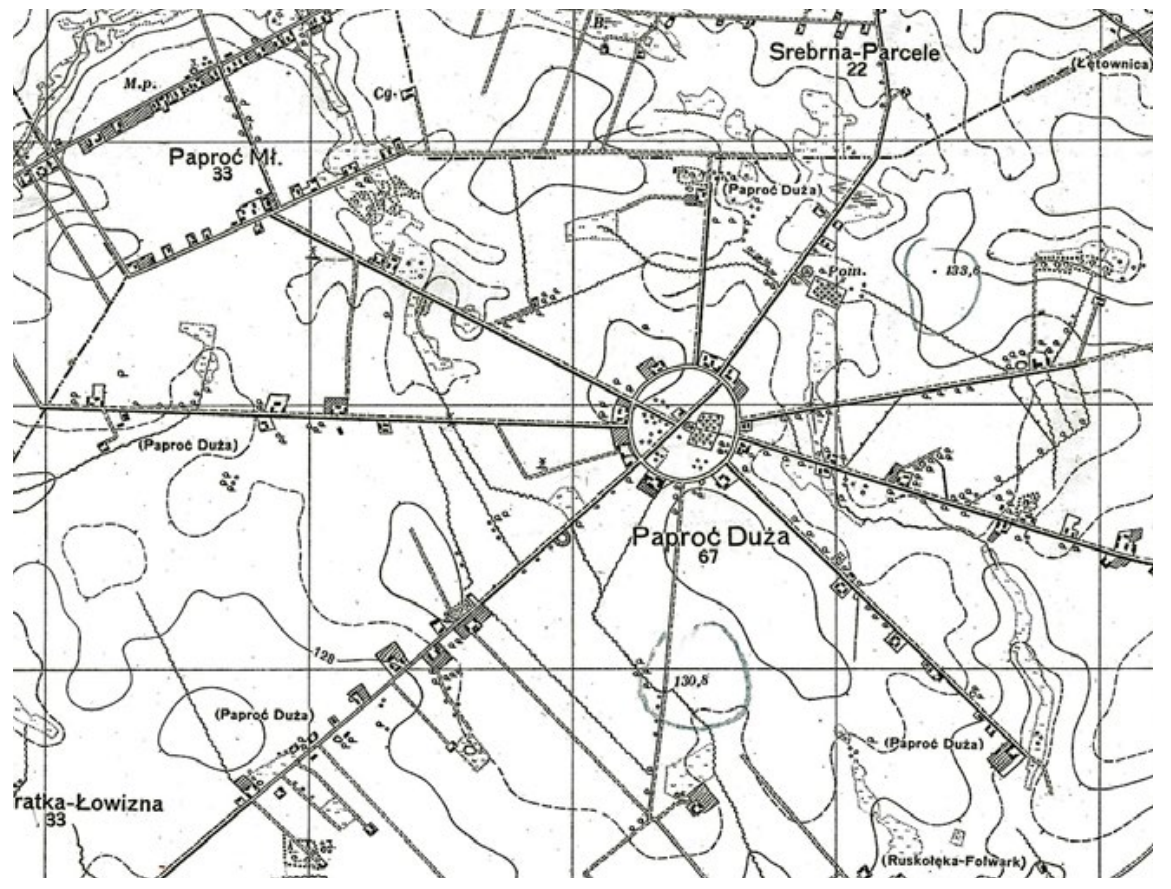

Ryc. 5. Paproć Duża - fragment Mapy szczegótowej Polski, opr. Wojskowy Instytut Geograficzny, Warszawa 1934

Źródło: http://maps.mapywig.org/m/WIG_maps/ series/025K/P37-S34-E_SREBRNA_1934.jpg

Budowa kościoła i towarzyszących mu zabudowań: domu pastora i służby kościelnej oraz budynków gospodarczych, rozpoczęła się w roku 1838. Kościół usytuowano zgodnie z pierwotnym planem układu przestrzennego wsi: w centrum kolistego placu, na przecięciu przedłużonych osi wszystkich dróg. Projekt przygotowany przez nieznanego z imienia budowniczego powiatowego o nazwisku Mettier, przewidywał budowę ścian

24 Topograficzna Karta Królestwa Polskiego (Mapa Kwatermistrzostwa), 1839 - [1843], Oryg. AGAD Warszawa, Zbiór Kartograficzny, K.V.S. III.

25 AGAD, CWW sygn. 1209, s. 3-4.

26 Stownik Geograficzny Królestwa Polskiego i innych krajów słowiańskich, T. VII, Warszawa 1886, s. 851.

27 Mapa szczegółowa Polski, opr. Wojskowy Instytut Geograficzny, Warszawa 1934, karta P 37-534-E SREBRNA. 
z bali drewnianych w konstrukcji wieńcowej na kamiennej podmurówce ${ }^{28}$. W trakcie budowy zapadła decyzja o wzniesieniu kościoła w całości murowanego, na co uzyskano zgodę Komisji Rządowej Spraw Wewnętrznych w 1841 r. ${ }^{29}$ Nowy plan i kosztorys zostały przedstawione władzom gubernialnym w następnym roku, kiedy budowa - jak pisano - była już „bliska ukończenia"30. Sporządził je następca budowniczego Mettier, architekt powiatowy Jaroszewski, który przejął nadzór nad budową świątyni. Ostateczne zakończenie prac wykończeniowych nastąpiło roku 1848.

Wygląd kościoła ewangelickiego w Paproci Dużej możemy odtworzyć w ogólnym zarysie na podstawie fragmentarycznych opisów i skąpych materiałów ikonograficznych, nie zachowały się bowiem wymieniane w źródłach rysunki projektowe. Była to niewielka jednoprzestrzenna świątynia o wymiarach korpusu nawowego 18,6×12 m, nakryta dwuspadowym dachem, z wieżą w elewacji frontowej zwieńczoną ostrosłupowym hełmem z krzyżem (Ryc. 6). Fasada trójosiowa, pierwotnie zaprojektowana jako klasycyzująca z podziałami pilastrowymi, których finalnie jednak nie wykonano ${ }^{31}$. Na osi środkowej fasady umieszczono główne wejście do kościoła, prostokątne z półkolistym nadświetlem flankowane po bokach parą wysokich prostokątnych okien zwieńczonych wydatnymi profilowanymi gzymsami. Takież gzymsy wieńczyły tynkowane elewacje i oddzielały drugą kondygnację wieży.

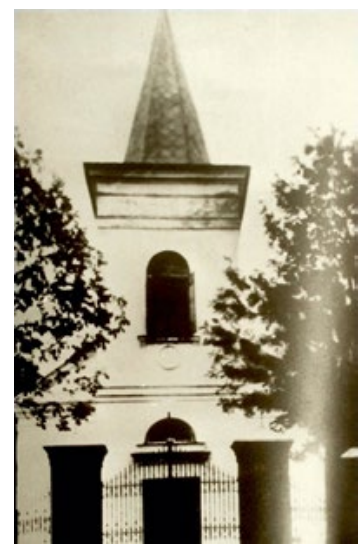

Ryc. 6. Fasada kościoła ewangelickiego w Paproci Dużej, widok przed 1939. Fot. w zbiorach autorki

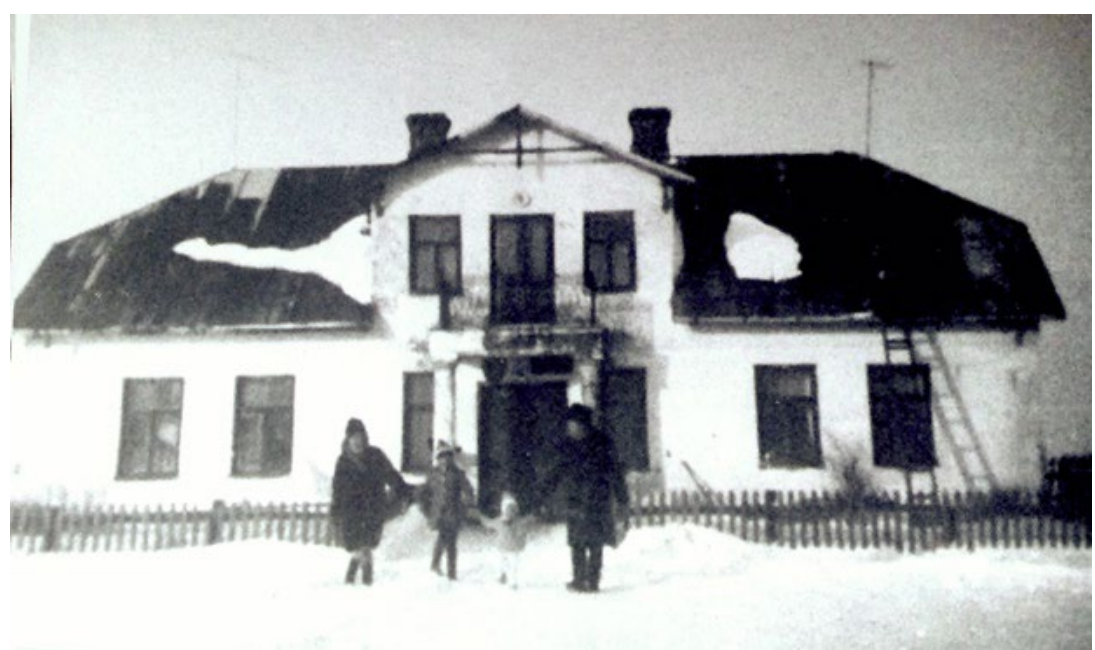

Ryc. 7. Paproć Duża, dawny dom pastora, widok przed 1939. Fot. w zbiorach autorki

Naprzeciw kościoła po drugiej stronie drogi przecinającej kolisty plac, znajdowała się plebania wraz z zabudowaniami gospodarczymi. Dom pastora wybudowano w konstrukcji drewnianej, jednak w latach 1856-59 r. wzniesiono w jego miejscu nowy, murowany budynek, gdyż "dawniejsza plebania drewniana przed kilkunastu laty zaledwie wystawiona uległa zupełnemu zniszczeniu przez stoczenie owej grzybem drzewnym"32. Nowy plan i kosztorys sporządził nieznany z imienia budowniczy powiatu ostrołęckiego - Jaroszewski. Budynek był murowany z cegły, tynkowany, z dachem naczółkowym krytym dachówką, jednokondygnacyjny z wgłębnym portykiem ujętym parą toskańskich kolumn (Ryc. 7). Dom mieścił mieszkanie pastora „z trzech stancji złożone" oraz kancelarię, kuchnię i spiżarnię.

29 AGAD, CWW sygn. 1210, s. 202: Komisja Rządowa reskryptem z d. 7 II 1841 dozwolita, aby w miejsce kościoła z drzewa wzniesiony zostat murowany z zastrzeżeniem przedstawienia planu i aby koszta nie przewyższyły pierwotnego.

30 Ibidem.

31 W piśmie Wydziału Wyznań z Rządem Gubernialnym Płockim wskazującym na uchybienia popełnione przy budowie kościoła ewangelickiego w Paproci Dużej pisano m.in., że w fasadzie „opuszczono pilastry, nie dano ram obwodowych około okien, zrobiono okno nad drzwiami frontowymi nieforemne" zaś w wnętrzu „kapitele filarów (...) pod samym sufitem urządzono". Podjęto jednocześnie decyzję o nieuzupełnianiu brakujących pilastrów, ponieważ dodane do istniejącej już elewacji nie pełniłyby już żadnej funkcji konstrukcyjnej. AGAD, CWW sygn. 2010, s. 229.

32 AGAD, CWW, sygn. 1210, s. 227, 388, 396. Usytuowanie domu pastora było niezgodne z pierwotnym planem, w którym dom ten wraz z gospodarstwem przewidziano jako jedno z dziewięciu siedlisk przylegających do okrężnicy. 
Poza wymienionymi budowlami rozległy plac pozostał niezabudowany, utrzymując reprezentacyjny charakter zamierzony w pierwotnym projekcie rozplanowania wsi. Na zewnątrz drogi okrężnej zaprojektowano dziewięć gospodarstw, pozostałe sytuowano wzdłuż promienistych dróg prowadzonych do kolonii. Zagrody osadników miały znormalizowane rozplanowanie: dom mieszkalny znajdował się w głębi prostokątnej posesji, po bokach gumna naprzeciw siebie stały stodoła i stajnia ${ }^{33}$. Drobny inwentarz przechowywano w wydzielonej części domu mieszkalnego. Domy w większości budowane były w konstrukcji ryglowej lub z bali drewnianych konstrukcji zrębowej, zawsze na wysokiej podmurówce z kamieni polnych, dachy kryto strzechą. (Ryc. 8) Zalecane było obsadzanie drzewami granic działek i skrajów dróg. Krajobraz wsi wzbogacały ponadto dwa wiatraki typu koźlak: jeden stał na polu Rudolfa Kocha (obecnie Paproć Duża 72) do roku 1915, kiedy spłonął; drugi był własnością młynarza Buse'go - usytuowany przy drodze do Paproci Małej, został zniszczony w 1941 r.

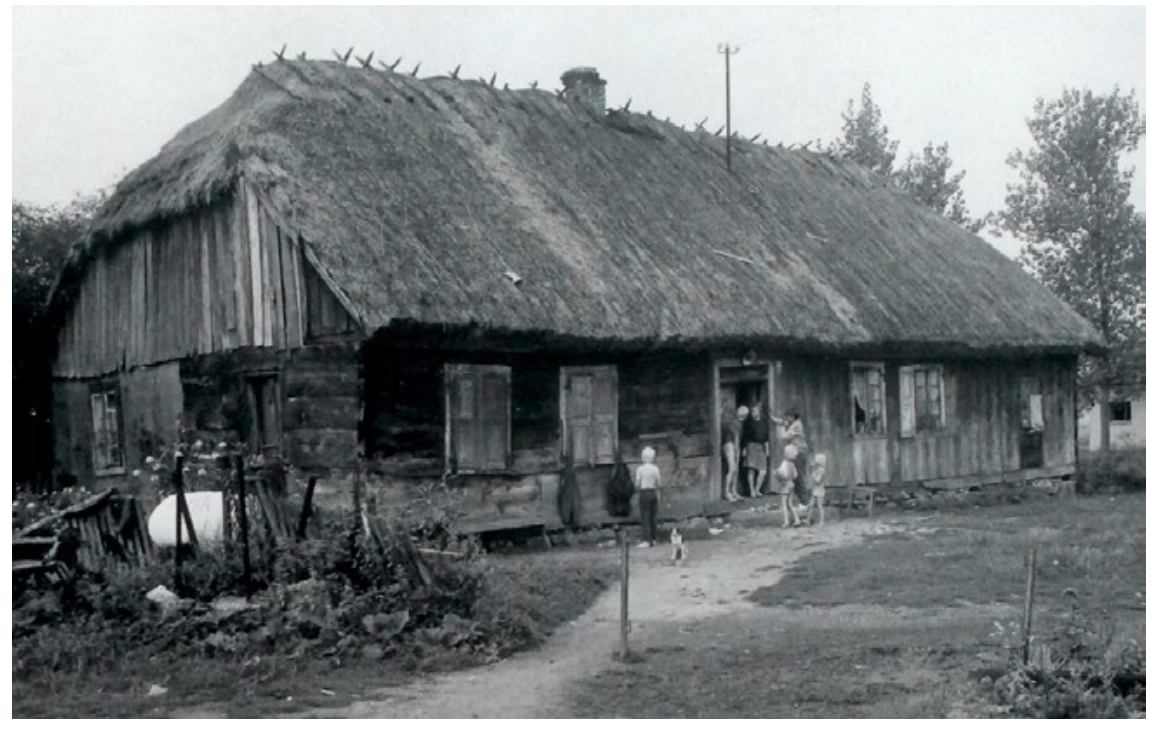

Ryc. 8. Paproć Duża, dom mieszkalny - zachowany przykład pierwotnej zabudowy wsi. Fot. Adam Dolistowski, 1990

Zabudowa Paproci Dużej w XX wieku uległa dwukrotnie całkowitemu zniszczeniu. Po raz pierwszy w 1915 r., kiedy w wyniku działań wojennych spłonęły wszystkie budynki oprócz kościoła i plebanii, jednego domu mieszkalnego i wiatraka. W dwudziestoleciu międzywojennym wszystkie domy i budynki gospodarcze odbudowano z zachowaniem tradycyjnych form i technologii. Po II wojnie światowej naturalne zmiany modernizacyjne spowodowały stopniowe wypieranie dotychczasowej tradycyjnej zabudowy, w wyniku tego procesu na początku lat 90. XX w. została ona całkowicie wyeliminowana z krajobrazu wsi ${ }^{34}$. Drewniane domy mieszkalne i obiekty gospodarcze zostały zastąpione przez standardową zabudowę murowaną.

Kościół ewangelicki przetrwał w swym pierwotnym stanie i przeznaczeniu do wybuchu II wojny światowej, służąc nieprzerwanie miejscowej społeczności ewangelickiej. Po 1939 r. świątynia przestała być miejscem kultu - wysiedleni parafianie wyjeżdżając zabrali z sobą dzwon kościelny, zaś budynek kościoła nie powrócił już nigdy do swego właściwego przeznaczenia. W latach II wojny światowej opustoszały kościół służył jako magazyn umundurowania, po jej zakończeniu stał opuszczony, a następnie, od roku 1952 był użytkowany przez Spółdzielnię Produkcyjną w Paproci jako chlewnia. Po likwidacji spółdzielni obiekt stał nieużytkowany; w 1966 r. pozostałości zniszczonej budowli zostały sprzedane przez Konsystorza Ewangelicko-Augsburskiego miejscowemu rolnikowi z przeznaczeniem do rozbiórki. Opuszczony i zrujnowany obiekt został rozebrany w drugiej połowie lat 60. XX w. Historia tego miejsca, wciąż obecna w świadomości lokalnej społeczności, odżyła po 1990 r., kiedy mieszkańcy Paproci Dużej podjęli inicjatywę odbudowy świątyni ${ }^{35}$. Projekt autorstwa arch. Barbary Miron-Kaczyńskiej i Janusza Kaczyńskiego wykonano w nawiązaniu do historycznej sylwety kościoła z dostosowaniem jej

33 Müller, op. cit., s. $138-140$.

34 W 1990 r. w Paproci Dużej zachowane były zaledwie dwa domy mieszkalne wzniesione przed 1939 r. (nr 40, 44 ), oba w złym stanie technicznym.

35 Zob. A. Dolistowski, Wielki grzech Paproci Dużej, „Plus” nr 11 z dn. 24 XI 1990 
formy do obrządku rzymsko-katolickiego. Kościół pw. Miłosierdzia Bożego wybudowano w latach 1994-1998 jako filię parafii w Andrzejewie; zlokalizowano go w miejscu pierwotnego kościoła ewangelickiego, w centrum rozległego placu, przywracając tym samem pierwotną dominantę kompozycyjną tej przestrzeni ${ }^{36}$ (Ryc. 9, 10).

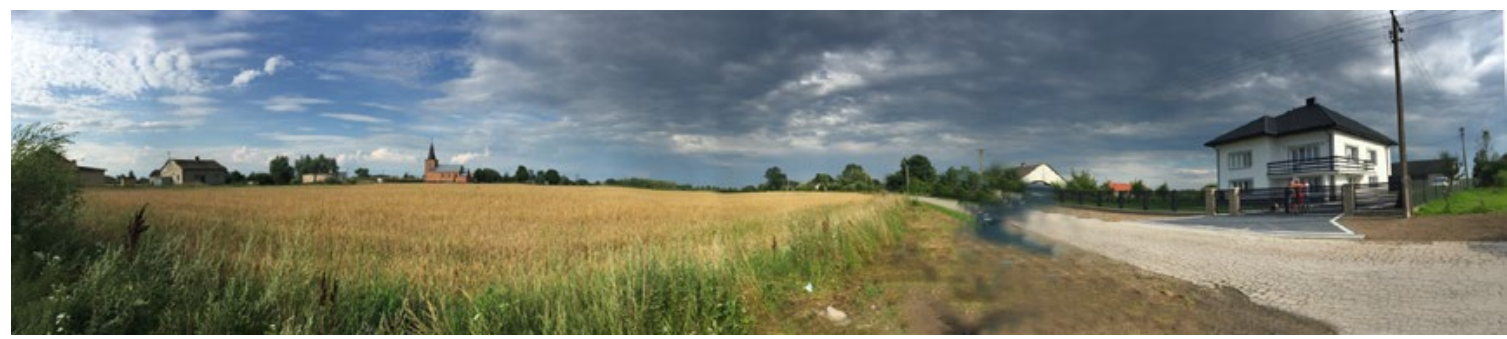

Ryc. 9. Paproć Duża, widok panoramiczny centrum wsi. Fot. Małgorzata Dolistowska, 2017

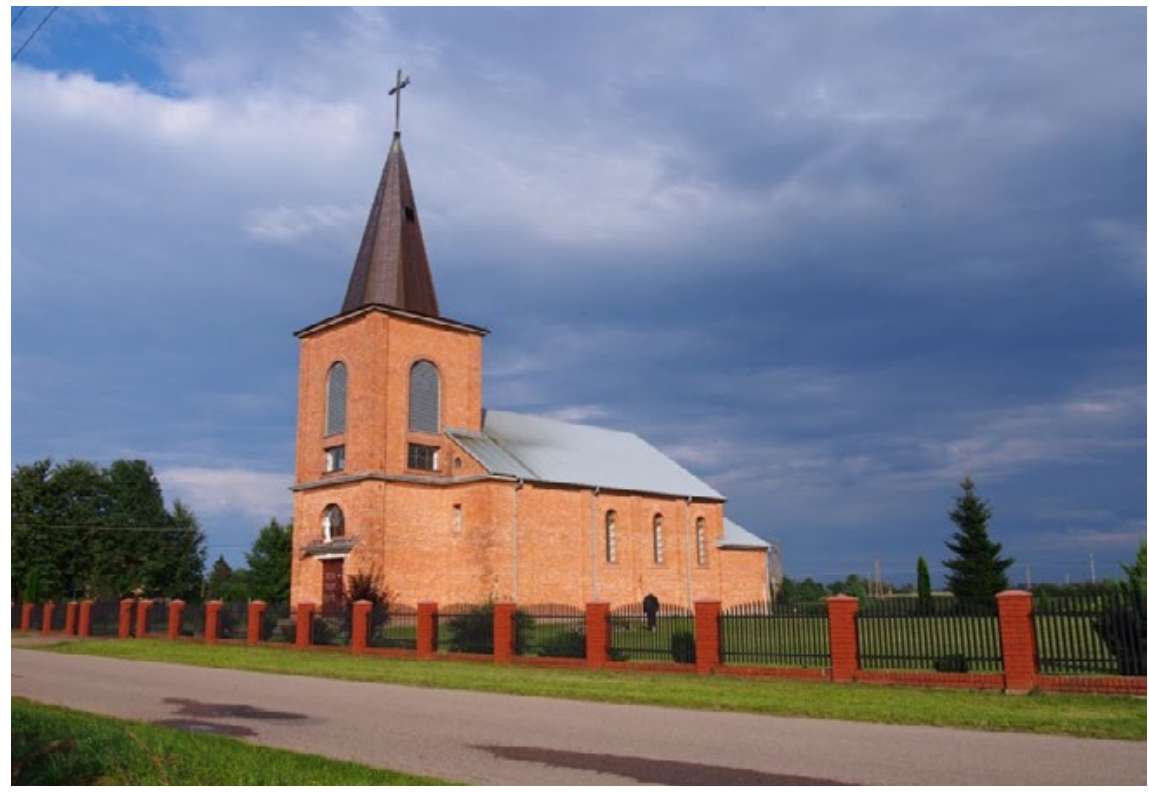

Ryc. 10. Kościół pw. Miłosierdzia Bożego w Paproci Dużej. Fot. Małgorzata Dolistowska, 2017

\section{Analiza układu przestrzennego}

Wieś Paproć Duża zachowała czytelny do dzisiaj, pomimo dwudziestowiecznych przeobrażeń, oryginalny promienisto-centralny układ ruralistyczny z końca XVIII w. Ten sam schemat zachował się Polsce w zaledwie kilku miejscowościach: we wsiach osadniczych Kup i Pokój na Śląsku Opolskim oraz w dawnej wsi Nowosolna, obecnie włączonej jako osiedle w granice administracyjne Łodzi. Analogicznie rozplanowana była również osada hutnicza w Jedlicach, jednak jej pierwotny kształt przestrzenny nie przetrwał, pozostały tylko szczątkowe relikty pierwotnej zabudowy. Wymienione miejscowości - odległe geograficznie i położone w regionach o różnej tradycji historycznej - łączy wspólna cecha: wszystkie powstały w ramach różnych etapów kolonizacji fryderycjańskiej na terenach włączonych w drugiej połowie XVIII w. do Królestwa Prus i były objęte pruskim systemem prawno-administracyjnym.

Program kolonizacji obszarów niezurbanizowanych i najsłabiej zaludnionych w nowo pozyskanych terytoriach, odgrywał rolę szczególnie istotną w polityce króla Fryderyka II Wielkiego, a następnie kolejnych monarchów tej dynastii (Fryderyka Wilhelma II i Fryderyka Wilhelma III). Najwcześniej sytuacja ta nastąpiła na Śląsku, 
przyłączonym do państwa pruskiego po roku 1740. Akcję osadniczą realizowano na tym obszarze w latach 1741-1805, zarówno w ramach zasiedlania wsi już istniejących, jak i przez budowę nowych osad państwowych i prywatnych ${ }^{37}$. Rozwiązania przestrzenne, technologiczne i funkcjonalne były regulowane centralnie. Edykt królewski z 1773 roku zalecał stosowanie w nowo zakładanych miejscowościach rozplanowania linearnego o stypizowanym schemacie opartym na wydłużonym, geometrycznym układzie dwóch rzędów zagród rozdzielonych wewnętrzną drogą przelotową. Według powyższych wytycznych założono Śląsku ponad czterysta nowych kolonii osadniczych. Wśród nich wyróżniają się pojedyncze miejscowości zaprojektowane odmiennie, tj. w oparciu o układ koncentryczno-radialny; były to mianowicie: osada hutnicza w Jedlicach (Jedlitz), ośrodek administracyjny i kolonia rzemieślnicza w Kup (Kupp) oraz wieś Marienau ${ }^{38}$. Na Śląsku po raz pierwszy zastosowano ten schemat przestrzenny w barokowym założeniu rezydencjonalnym w miejscowości Pokój (Carlsruhe) nieopodal Opola, zaprojektowanym w 1748 r. przez architekta Georga Ludwiga Schirrmeistera dla księcia wirtembersko-oleśnickiego Karola Christiana Erdmana ${ }^{39}$.

Osadę w Jedlicach i kolonię w Kup zrealizowano według planu pruskiego architekta Johanna M. Pohlmanna działającego na Śląsku od lat 60. XVIII w. aż do śmierci w $1800 \mathrm{r}^{40}$ Kolonia robotnicza wraz z hutą w Jedlicach zaprojektowana została przez Pohlmanna w 1775 r. w sposób daleko odbiegający od wytycznych edyktu królewskiego regulujących zabudowę nowych osad. Założenie miało układ radialny, oparty o rzut koła o średnicy ok. $400 \mathrm{~m} \mathrm{z}$ wewnętrznym okrągłym placem, od którego odchodziły promieniste aleje (Ryc. 11). Plac ze studnią, obsadzony wysoką zielenią, otoczony był podwójnym pierścieniem zabudowy rozdzielonym wewnętrzną drogą-okolnicą i podzielonym na trapezoidalne parcele budowlane. W sektorach bezpośrednio przylegających do centralnego placu usytuowano budynki huty oraz domy mieszkalne ustawione kalenicowo wokół przestrzeni centralnej; domy po drugiej stronie wewnętrznej drogi usytuowane były kalenicowo.

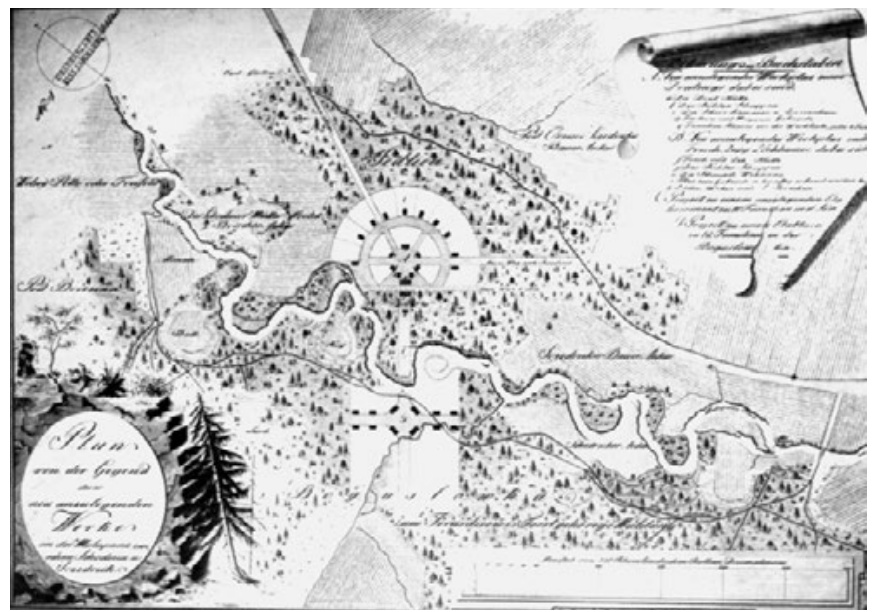

Ryc. 11. Plan kolonii hutniczej w Jedlicach, $1775 \mathrm{r}$.

Źródło: H.J. Helmigk, Oberschlesiscje Landbaukunst um 1800, Berlin 1937, s. 248.

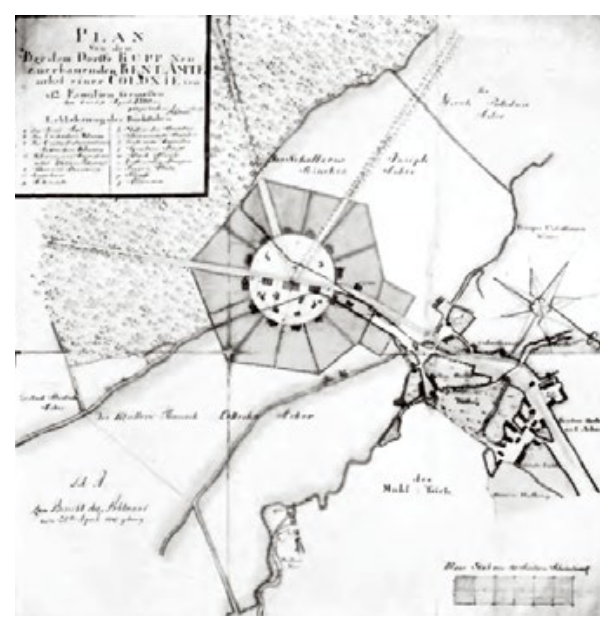

Ryc. 12. Plan kolonii w Kupp, 1780.

Źródło: H.J. Helmigk, Oberschlesiscje Landbaukunst um 1800, Berlin 1937, s. 200.

Drugim chronologicznie założeniem o nietypowym koncentrycznym kształcie, powstałym według projektu Pohlmanna była miejscowość Kup (Kupp) na pruskim Śląsku. Architekt zaprojektował ją w 1780 r. jako kolonię rzemieślniczą a zarazem ośrodek administracyjny - swoiste centrum zarządzania dla zespołu około 30 wsi i nowych kolonii położonych na północ od Opola. Podobnie jak w poprzednim projekcie kompozycja

37 M.E. Adamska, Kolonizacja fryderycjańska na Śląsku/Schlesien 1771-1805, [w:] Architektura ryglowa - wspólne dziedzictwo. Kolonizacja fryderycjańska, Słubice 2014, s. 37-38.

38 Ibidem s. 46; M. Chorowska, A. Zabłocka-Kos, Założenia radialne na Ślasku Opolskim z okresu kolonizacji fryderycjańskiej, [w:] Prace Naukowe Instytutu Historii Architektury, Sztuki i Techniki Politechniki Wrocławskiej nr 19, Studia i materiały. Z badań architektury i sztuki Śląska, nr 9 , Wrocław 1988, s. 27-74.

39 Zob. M.E. Adamska, Johann Martin Pohlmann. Architekt epoki fryderycjańskiej, "Architectus” 2015, nr 1(41), s. 8-9.

40 Ibidem, s. 3-20. 
przestrzenna została zaprojektowana w układzie centralnym z kolistym placem obwiedzionym okolnicą i promieniście rozchodzącymi się drogami (Ryc. 12). Dominantę przestrzenną stanowił usytuowany w centrum placu budynek administracji państwowej - gmach urzędu podatkowego flankowany domami urzędników: kontrolera i kancelisty. Po przeciwnej stronie drogi otaczającej plac, w koncentrycznym układzie zlokalizowano domy kolonistów i zabudowania wiejskie (kuźnię, browar i gospodę).

Analogiczne do powyższych były okoliczności powstania dawnej wsi Nowosolna będącej obecnie jedną z dzielnic administracyjnych Łodzi. Jej teren wraz z połaciami Polski środkowej został po II rozbiorze Polski w 1793 r. zagarnięty przez Prusy; skonfiskowano wówczas rozległe dobra królewskie i kościelne oraz utworzono nową prowincję - Prusy Południowe. Akcja zasiedlania tego obszaru osadnikami niemieckimi rozpoczęła się w 1797 r., a jej celem było skierowanie emigracji z przeludnionych prowincji południowych Rzeszy (Wirtembergii, Badenii, Palatynatu) do Prus Południowych i Nowych Prus Wschodnich ${ }^{41}$. Nowe miejscowości zakładane przez władze pruskie na tym obszarze cechowały się - podobnie jak na Śląsku - regularną, linową zabudową. Oryginalnym, koncentrycznym układem wyróżniała się wśród nich miejscowość Neu Sulzfeld (Nowosolna), jedna z największych i najludniejszych osad pruskich powstałych w ramach akcji kolonizacyjnej, kierowanej przez ministra Ottona von Vossa. Wieś Neu Sulzfeld została założona w 1801 r. na terenie istniejącej tu od XIV w. dawnej wsi królewskiej Wiączyn Polny, jej nazwa nawiązywała bezpośrednio do miejsca pochodzenia większości pierwszych osadników - miejscowości Sulzfeld w północnej Badenii ${ }^{42}$. W 1802 został sporządzony plan miejscowości ${ }^{43}$. (Ryc. 13) Ukazuje on charakterystyczny układ z centralnym placem, od którego odchodzi promieniście osiem prostoliniowych dróg prowadzących do okolicznych miejscowości oraz dodatkowo pomiędzy nimi osiem promieni pomocniczych wyznaczających podział gruntów rolnych. Kolisty plac miał charakter przestrzeni wspólnej z cmentarzem i kościołem pośrodku, u zbiegu dróg wyznaczone były niewielki działki przeznaczone dla rzemieślników i na obiekty użyteczności publicznej (karczma, kuźnia, wspólna studnia) ${ }^{44}$. Zagrody kolonistów rozmieszczono w regularnych odstępach po obu stronach dróg.

Wszystkie przytoczone przykłady cechuje ten sam schemat rozplanowania: koncentryczno-promienisty z centralnym placem pośrodku, od którego odchodzą prostoliniowe drogi lub aleje widokowe. Struktura ta wypełniona była jednak rozmaitą treścią ideową wyrażoną poprzez główne atrybuty przestrzenne i zagospodarowanie placu centralnego. Rozległe, wielokierunkowe założenie rezydencjonalno-parkowe w miejscowości Pokój (Carlsruhe) z dominantą w postaci pałacu książęcego miało barokową jeszcze genezę, nawiązując w swej formie do urbanistyki swego bardziej okazałego imiennika - Karlsruhe, stolicy Badenii. Obydwa projekty Joachima Martina Pohlmanna (kolonia hutnicza w Jedlicach i ośrodek administracyjny w Kup) wyrażają już idee oświeceniowego postępu i racjonalizmu, wykazując wpływy francuskiej awangardowej myśli urbanistycznej ${ }^{45}$. Najbliższą analogię dla projektu wsi Paproć Duża stanowi plan miejscowości Nowosolna. Identyczny jest nie tylko ogólny schemat koncentryczno-radialny, lecz również ten sam sposób zagospodarowania środkowej części wspólnej z dominantą w postaci bryły świątyni. Projekt rozplanowania tej przestrzeni sporządzony dla wsi Königshuld (Paproć Duża), jest chronologicznie wcześniejszy i bardziej precyzyjnie ukazuje naczelną ideę dążenie do uzyskania idealnej formy centralnej, z wpisaniem w kolistą przestrzeń placu dwóch cmentarnych alei tworzących krzyż równoramienny i kościołem na ich przecięciu. Szpalery zieleni, którymi obsadzono wszystkie linie graniczne podkreślają precyzyjną symetrię rozplanowania. Równie regularnie rozplanowane są zabudowania posesji ułożonych radialnie wzdłuż pierścienia okrężnej alei; właścicielami kilku z nich były osoby ważne dla funkcjonowania wspólnoty: pastor, nauczyciel i zarządca kolonii. Należy ponadto zwrócić uwagę na fakt, że obydwie miejscowości zostały zaplanowane jako punkty centralne w nowo konstruowanej sieci osadniczej na danym obszarze. Projekt rozplanowania centrum Königshuld (Paproci Dużej) jest niedatowany i niesygnowany; z przekazów archiwalnych wiadomo jednak, że powstał w roku 1799 i jego autorem był nieznany z imienia

41 K.P. Woźniak, Niemieckie osadnictwo wiejskie między Prosna a Pilica i Wisła od lat 70. XVIII wieku do 1866 roku. Proces i jego interpretacje, Łódź 2013, s. 80-81.

42 T. Figlus, Geneza, rozwój i zanik Wiączynia. Próba rekonstrukcji geograficzno-historycznej osadnictwa w aspekcie przemian zagospodarowania przestrzennego i rozplanowania wsi, "Studia z Geografii Politycznej i Historycznej”, T. 6 (2017), s. 200-201. Trzy nowe jednostki osadnicze powstały również w miejscu sąsiedniej wsi Wiączyn Leśny W czasach Królestwa Kongresowego założone w czasach zaboru pruskiego wsie otrzymały nazwy polskie: Nowosolna, Wiączyn Górny, Wiączyn Dolny, Wiączyn Nowy.

43 BUW, Gabinet Rycin, sygn. GR 300, zob.: Woźniak, op. cit., Aneks X, s. 347.

44 W 1803 r. wzniesiono w Neu Sulzfeld pierwszy budynek szkoły, w 1805 r. - stanął kościół: Woźniak, op. cit., s. 203.

45 M. Adamska, Johann Martin Pohlmann..., op. cit., s. 12. 
radca Kamery von Wedell. Plan wsi Neu Sulzfeld (Nowosolnej) zawiera adnotację Vermessen und eingetheilt im Jahr 1802 durch Küntzel, wskazującą na datę rozmierzenia ziemi i wytyczenia działek oraz nazwisko mierniczego, być może również autora koncepcji.

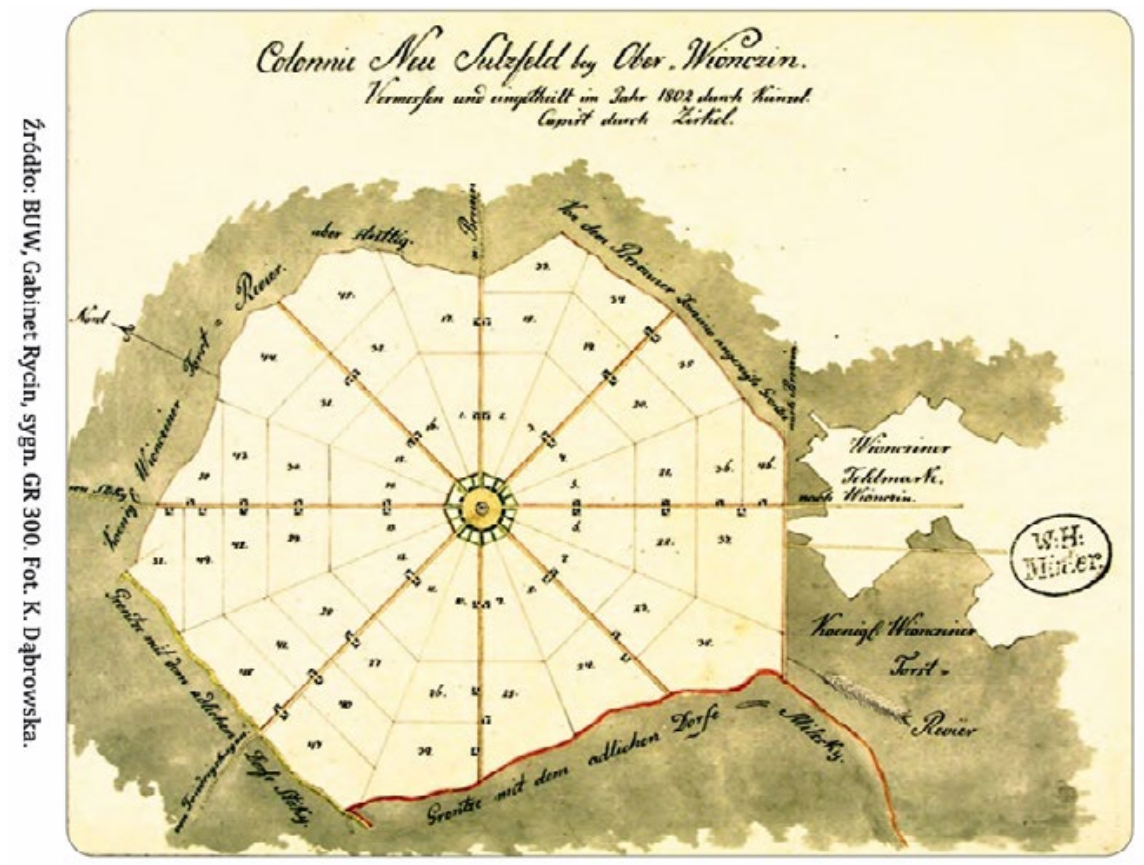

Ryc. 13. Plan kolonii Neu Sulzfeld, 1802

Źródło: K.P. Woźniak, Niemieckie osadnictwo wiejskie między Prosna a Pilica i Wista od lat 70. XVIII wieku do 1866 roku. Proces i jego interpretacje, Łódź 2013, s. 347

Geneza obydwu założeń - Paproci Dużej i Nowosolnej, podobnie jak w analogicznych przykładach śląskich tkwi we francuskiej teorii architektury 2. połowy XVIII wieku, której wpływy wyraźnie widoczne są w architekturze Prus tego okresu. Kluczową rolę w ukształtowaniu przestrzeni i zabudowy obydwu miejscowości mógł odegrać David Gilly (1748-1808), jeden z najważniejszych i najbardziej wpływowych architektów pruskich tego okresu. Jako wysoki rangą urzędnik centralnego szczebla administracji państwowej w Berlinie był odpowiedzialny bowiem za działalność budowlaną i planowanie przestrzenne na Pomorzu oraz terenach przyłączonych do Prus w wyniku kolejnych rozbiorów Polski, w tym również Prus Nowowschodnich i Prus Południowych ${ }^{46}$. W swojej praktyce architektonicznej, działalności administracyjnej i dydaktycznej propagował idee wywodzące się wprost z racjonalistycznego nurtu francuskiego klasycyzmu - architektury oszczędnej, opartej na projektach typowych i znormalizowanych wzorcach. Na obszarach kolonizowanych proponował wykorzystanie łatwo dostępnych, lokalnych materiałów tj. drewna i gliny. Jego poglądy wyrażane również w publikacjach książkowych oraz w działalności dydaktycznej, ukształtowały i ukierunkowały działalność państwowych wydziałów budowlanych przy kamerach. Zatrudnieni w nich inspektorzy posiadający uprawnienia projektowe legitymowali się dobrym przygotowaniem zawodowym, potwierdzonym egzaminami państwowymi i byli w większości absolwentami Akademii Budownictwa (Bauakademie) w Berlinie, której współtwórcą i wykładowcą był David Gilly. Do grona tego mogli należeć również projektanci Paproci Dużej i Nowosolnej.

\section{Podsumowanie}

Po ponad dwustu latach od swego powstania wieś Paproć Duża, należąca do nielicznej grupy miejscowości na planie koncentryczno-radialnym założonych na ziemiach polskich w ramach kolonizacji fryderycjańskiej, zachowała swój oryginalny układ przestrzenny w niemal niezmienionej formie. Ten rzadko spotykany w historii 
ruralistyki promienisty schemat przetrwał pomimo burzliwej historii miejscowości - w sposób wręcz unikatowy w swojej jednorodności, co wyróżnia go na tle innych, jednostkowo zachowanych podobnych założeń w Polsce. W dziejach północno-wschodniego Mazowsza stanowi natomiast świadectwo mało znanego epizodu pruskiego i tym samym jest ważną częścią kulturowego dziedzictwa regionu.

\title{
Literatura
}

[1] Adamska E.M., Kolonizacja fryderycjańska na Śląsku/Schlesien 1771-1805, [w:] Architektura ryglowa - wspólne dziedzictwo. Kolonizacja fryderycjańska, Słubice 2014.

[2] Adamska M.E., „Architectus” 2015, nr 1(41), s. 8-9.

[3] Chorowska M., Zabłocka-Kos A., Założenia radialne na Ślasku Opolskim z okresu kolonizacji fryderycjańskiej [w:] Prace Naukowe Instytutu Historii Architektury, Sztuki i Techniki Politechniki Wrocławskiej nr 19, Studia i materiały. Z badań architektury i sztuki Śląska, nr 9, Wrocław 1988, s. 27-74.

[4] Figlus T., Geneza, rozwój i zanik Wiączynia. Próba rekonstrukcji geograficzno-historycznej osadnictwa w aspekcie przemian zagospodarowania przestrzennego i rozplanowania wsi, „Studia z Geografii Politycznej i Historycznej”, T. 6 (2017), s. $183-208$.

[5] Kamiński A., Pogranicze polsko-rusko-jaćwieskie między Biebrza i Narwiq, „Rocznik Białostocki”, T. IV, Białystok 1963.

[6] Kneifel E., Die evangelisch-augsburgischen Gemeinden in Polen 1555-1939, Vierkirchen über München 1971.

[7] Kneifel E., Die Pastoren der evang.-augsb. Kirche in Polen, Nürnberg 1961.

[8] Müller A., Die preussische Kolonisation in Nordpolen und Litauen 1795-1807, Berlin 1928.

[9] Pytlak A., Die deutsche Kolonisationbestrebungen auf den Staatsdomänen im Königsreiche Polen von 1793-1864, Lepzig 1917.

[10] Stegner T., Przyjaciel Marszatka pastor Kacper Mikulski (1840-1935), "Gdański Rocznik Ewangelicki", vol. 3 (2009).

[11] Teut A., David Gilly 1748-1808. Ein preußischer Landbaumeister Leben - Werk - Wirkung, Berlin 2008.

[12] Wąsicki J., Ziemie polskie pod zaborem pruskim: Prusy Nowowschodnie (Neuostpreussen) 1795-1806, Poznańskie Towarzystwo Przyjaciół Nauk, Prace Komisji Historycznej, Vol. XX, Part 1, Poznań 1963.

[13] Wiśniewski J., Rys dziejów osadnictwa na wschodnim Mazowszu. „Literatura Ludowa” R. Vl:1962;

[14] Woźniak K.P., Niemieckie osadnictwo wiejskie między Prosna a Pilica i Wista od lat 70. XVIII wieku do 1866 roku. Proces i jego interpretacje, Łódź 2013.

[15] Żuchowski T., David Gilly und die Ostgebiete Preußens, [w:] David Gilly - Erneuerer der Baukultur, (hrsg.) E. Führ, A. Teut, Münster-New York-München-Berlin 2008, s. 61-78.

\section{The ideal village - spatial arrangement and building of Paproć Duża}

\begin{abstract}
The article presents the circumstances of the creation and history of the village of Paproć Duża founded at the end of the $18^{\text {th }}$ century under the name Königshuld as part of a settlement action covering the non-colonized areas of East Prussia. Among other places that were located at the time, it is distinguished by its original spatial development, based on a concentric-radial scheme. An analysis of the central spatial assumption was made in the context of the few analogical villages, founded in Poland in the second half of the $18^{\text {th }}$ century as part of the Frederician colonization.
\end{abstract}

Keywords: Paproć Duża, central arrangements, Neuostpreussen, Frederican colonization, Königshuld 